\title{
Flowering synchronization in hybrid rice parental lines
}

\section{Vitor Henrique Vaz Mondo ${ }^{1}$, Adriano Stephan Nascente ${ }^{1 *}$, Péricles de Carvalho Ferreira Neves ${ }^{1}$, James Emile Taillebois ${ }^{2}$, Manoel Oliveira Alves Cardoso Neto ${ }^{3}$}

\author{
${ }^{1}$ Brazilian Agricultural Research Corporation (EMBRAPA), Rice and Beans Research Center, PO Box 179, \\ 75375-000, Santo Antônio de Goiás, State of Goiás, Brazil \\ ${ }^{2}$ CIRAD - Centre de Coopération Internationale en Recherche Agronomique pour le Développement. \\ 3Uni-anhanguera University, Goiânia, Goiás, Brazil
}

*Corresponding author: adriano.nascente@embrapa.br

\begin{abstract}
The cultivation of hybrid rice is a technology that allows for an increase in grain yield of $30 \%$ relative to the grain yield of conventional cultivars. However, the main challenge for this technology is related to seed production, which has high production costs and low seed yields. Therefore, agronomic techniques that could enhance flowering synchrony of parental lines in the field are essential for an efficient production system of hybrid rice seeds. The objective of this work was to study the effects of sowing depth, plant density and fertilization with nitrogen or phosphorus as potential techniques to increase the pollen availability in the field and, consequently, the flowering synchrony between parental lines in the production of hybrid rice seeds. The experiments were conducted during two growing seasons in the Central Region of Brazil. All of the experiments were conducted as a randomized complete block in a split plot scheme; however, the experiment with $\mathrm{P}$ fertilization had a factorial design. Our research allow inferring that nitrogen fertilization technique applied to the soil or foliar at the time of panicle differentiation does not affect the time of onset of flowering of rice varieties INTA Puitá CL and L106R, which are potential R lines for the production of hybrid rice. Agronomic techniques of variation in sowing depth, seeding rate and the phosphate fertilization affect the time of onset of flowering from 10 to 19 degree-days, which could represent two days in the crop cycle, for the line L106R. Such techniques constitute potential alternatives for use in hybrid rice seed production systems and could be applied in alternated blocks of R lines in the field to obtain longer periods of pollen availability in the field.
\end{abstract}

Keywords: Oryza sativa L., agronomic strategies, flowering synchronization, growing-degree-days, fertilization. Abbreviations: DD_degree days; MST_male-sterility technique; NTS_no tillage system; Kc_crop coefficient; AWC_available water capacity.

\section{Introduction}

Rice is an important component of the diet for a half of the world's population (Nascente et al., 2013; Prasad, 2011). Moreover, the demand for rice is increasing, and it is expected that more than 116 million additional metric tons will be required in the year 2035 compared with the world rice production in 2010 (GRiSP, 2013). Therefore, the development of technologies that result in a higher rice grain yield is necessary to meet this demand and feed the world (Akhter et al., 2007; Qin et al., 2013). Worldwide, especially in Asian countries, the use of hybrid rice has achieved a significant increase in the grain yield compared with the use of traditional cultivars (Yadav and Srivastava, 2006; Tan et al., 2002). According to Ravi et al. (2007), Krishnakumar et al. (2005) and Virmani (2003), in countries such as China and India, the use of hybrid rice raised the average grain yield by $15-30 \%$ compared with traditional methods. These countries are the world's largest producers of rice and their cultivation of hybrid rice is widespread and has been used by farmers for more than 20 years (Kim et al., 2007). These increases in rice grain yield represent, on average, an increase in productivity from $10,000 \mathrm{~kg}$ to $13,000 \mathrm{~kg} \mathrm{ha}^{-1}$.
In the past decade, advances in the so-called super hybrid technology, obtained by performing inter species crossings (indica/japonica), has also brought further advances in grain yield of approximately $20 \%$ compared with conventional hybrids (Yuan, 2003). These results show the full potential of hybridization and its impacts in the supply chain of rice cultivation. However, in Western countries such as Brazil, rice hybrids are not widely used by farmers. One exception is the US, where the use of rice hybrids already represents a large share in the seed market. Currently, in Brazil, the seed market of hybrid rice is approximately $9 \%$ of the rice crop area, or 111,000 hectares, and is concentrated in the state of Rio Grande do Sul, Brazil's largest rice producing state (Planeta Arroz, 2015).

Rice hybrids, which have a high yield potential and yield stability (Kempe and Gils, 2011), can directly benefit food security, ensuring the production of a basic food for the Brazilian population and in other countries. This technology can also provide sustainability of agriculture with higher returns to farmers, allowing increasing food production per unit area. 
Mainly due to the characteristics of its floral structures, rice is a largely self-pollinating crop, making it unsuitable for outcrossing, with cross-pollination rates ranging only from 0 to $6.8 \%$ (Butany, 1957). However, some species of wild rice within the genus Oryza have outcrossing rates much higher than those of $O$. sativa (Oka, 1988). Species such as $O$. perennis may have cross-pollination rates between 20 to $45 \%$ (Oka and Morishima, 1967), and O. sativa $f$. spontanea has rates of 7 to $50 \%$ (Sakai and Narise, 1959); species such as $O$. longistaminata practically depend on outcrossing for reproduction (Virmani, 1996; Taillebois and Guimarães, 1988). Therefore, the main challenge in the production of hybrid rice seeds is to provide conditions for allogamy to occur naturally, making the seed production system efficient and economically viable.

To enable the production of hybrid rice seeds, various activities are required, the main one being the use of male sterility. Currently, the most used male-sterility technique (MST) is cytoplasmic, which was first reported in rice by Sampath and Mohanty (1954). With the use of male sterility, it is possible to achieve outcrossing rates that range from 5.0 to $7.5 \%$ under natural conditions (Kim et al., 2007). Although these rates are still insufficient for commercial seed production, rates above 40\% (Athwal and Virmani, 1972; Carnahan et al., 1972, Azzini and Rutger, 1982) and even higher, $53.1 \%$ have been reported (Xu and $\mathrm{Li}, 1988)$.

Based on the MST technology, the production of hybrid rice seeds requires a system composed of three lines: malesterile (line A), male-fertile with the ability to maintain sterility of the line A (line B) and another, also male-fertile, with the restored capacity for fertility in line A (line R). The combination of the first two lines ( $\mathrm{A}$ and $\mathrm{B})$ produces seeds that originate from male-sterile plants (line A seeds). The cross between $\mathrm{A}$ and $\mathrm{R}$ lines produces hybrid seeds originating from fertile plants (Bragantini et al., 2001).

In order for seed production to succeed, seed A and R lines must be sowed to ensure the synchronization of the flowering of lines, encouraging cross-pollination, which is a crucial factor in the production of hybrid seeds (Mao et al., 1998). Some techniques to synchronize the flowering of parental lines for the production of hybrid rice seeds have been studied for over 30 years, although few details, such as the application of nitrogen fertilizers, phosphate and other growth promoting chemicals, have been reported in literature (Huang et al., 1994). In addition, other potentially applicable techniques, such as the use of different seeding depths and densities, can be studied. In general, the aim of all these agronomic techniques is to identify optimal conditions for cross-pollination (Huang et al., 1994), which should be investigated to synchronize the timing of flowering between parental lines and to raise allogamy in the production of rice hybrid seeds.

Thus, this study tested the hypothesis that a change in rice crop management can affect the timing of the onset of flowering in the parental lines of plants. The objective of this work was to study the effect of sowing depth, plant density and fertilization with nitrogen or phosphorus as potential techniques to increase pollen availability in the field and, consequently, the flowering synchrony between the parental lines in the production of hybrid rice seeds.

\section{Results}

\section{Sowing depth}

There was no interaction between the factors for sowing depth (Table 2). The genotypes were different from each other, and cultivar INTA Puitá CL blossomed later than cultivar L106R. A greater sowing depth $(7.0 \mathrm{~cm})$ resulted in later flowering dates and differed from other depths ( 2.5 to $5.0 \mathrm{~cm}$ ), which did not differ from one another. This finding shows that the deeper seeding provided a delay for the seedlings to emerge, and it reflected the late start of the flowering period.

\section{Seeding rate}

Triple interaction in seeding density was observed (Table 2). Thus, in the 2012/2013 harvesting, the rice plants of both cultivars flowered earlier than the 2013/2014 growing season (Fig. 2).

The cultivar INTA Puitá CL was not affected by the seeding density (Fig. 2). On the other hand, the genotype L106R was significantly affected, and the data fit to a quadratic regression in the two years, with a reduction in the time to flowering onset with increasing plant density. These results are different from those reported by Rocha et al. (2011), which have shown that corn hybrids display an increase in the time to flowering onset with increasing seeding density. However, our results are interesting because they indicate that it is possible to change the flowering date of cultivar L106R by using different seeding rates.

\section{Nitrogen fertilization via soil and foliar}

There was a significant isolated effect of the genotype and growing season (Table 4). Thus, it was observed that the genotype INTA Puitá CL required a higher number of growing degree-days than did the line L106R to start flowering. $\mathrm{N}$ rates applied to the soil had no effect on flowering cultivars. However, at the foliar application of $\mathrm{N}$, differences between genotypes and growing seasons were observed (Table 5). The line INTA Puitá CL had a later flowering time than did the genotype L106R. However, as in the experiment involving the application of $\mathrm{N}$ in the soil, the $\mathrm{N}$ rates applied to leaves did not affect the time of onset of rice flowering.

\section{Phosphorus fertilization on soil and foliar}

There were singular effects of genotypes and growing seasons and a triple interaction between genotypes, growing seasons and phosphorus application to the soil (Table 6). Phosphorus fertilization did not affect the cultivation of INTA Puitá CL in either of the growing seasons (Fig. 3) but did affect the line L106R in the two growing seasons, with values fitted to quadratic equations. In the second growing season, the equation was significant, with decreasing values at increasing doses of $\mathrm{P}_{2} \mathrm{O}_{5}$.

\section{Discussion}

Our results show that growing seasons had an effect in all experiments and that harvest at a higher average temperature (2012/13) likely reduced the time to reach flowering compared with that of the growing season with lower average temperature (2013/14), confirming the effect of temperature on rice flowering. These findings may have been affected by climate conditions of the experimental site. In December of the 2012/2013 growing season, during the vegetative stage of the crop before flowering, the average temperature was $29.6{ }^{\circ} \mathrm{C}$, while in December of the 2013/2014 growing season, the average temperature was 27.8 ${ }^{\circ} \mathrm{C}$. Consistent with the findings of this study, it has been 
Table 1. Chemical soil attributes in the experimental area at the layer 0-0.20 $\mathrm{m}$ in the 2012/2013 and 2013/2014 growing seasons. Santo Antônio de Goiás, Brazil.

\begin{tabular}{|c|c|c|c|c|c|c|c|c|c|c|c|c|}
\hline $\begin{array}{l}\text { Growing } \\
\text { season }\end{array}$ & $\mathrm{pH}$ & SOM & $\mathrm{K}$ & $\mathrm{Ca}$ & $\mathrm{Mg}$ & $\mathrm{Al}$ & $\mathrm{H}+\mathrm{Al}$ & $\mathrm{P}$ & $\mathrm{Cu}$ & $\mathrm{Fe}$ & $\mathrm{Mn}$ & $\mathrm{Zn}$ \\
\hline & (water) & $\mathrm{g} \mathrm{dm}^{-3}$ & ----- & $---\mathrm{cn}$ & $\mathrm{dm}^{-3}$ & ------ & & & --mg & $1^{-3}-\cdots$ & ----- & \\
\hline $2012 / 13$ & 5.4 & 36.8 & 0.15 & 1.6 & 1.0 & 0.2 & 3.0 & 6.1 & 1.1 & 15.3 & 8.9 & 4.5 \\
\hline $2013 / 14$ & 5.5 & 33.3 & 0.34 & 1.3 & 0.7 & 0.1 & 3.8 & 7.5 & 1.1 & 18.0 & 9.4 & 4.2 \\
\hline
\end{tabular}

$\mathrm{pH}$ - hydrogen potential, SOM - soil organic matter, $\mathrm{K}$ - potassium, Ca - calcium, Mg - magnesium, Al - aluminum, $\mathrm{P}-$ phosphorus, B - boron, Fe - iron, Mn manganese, $\mathrm{Zn}-$ zinc
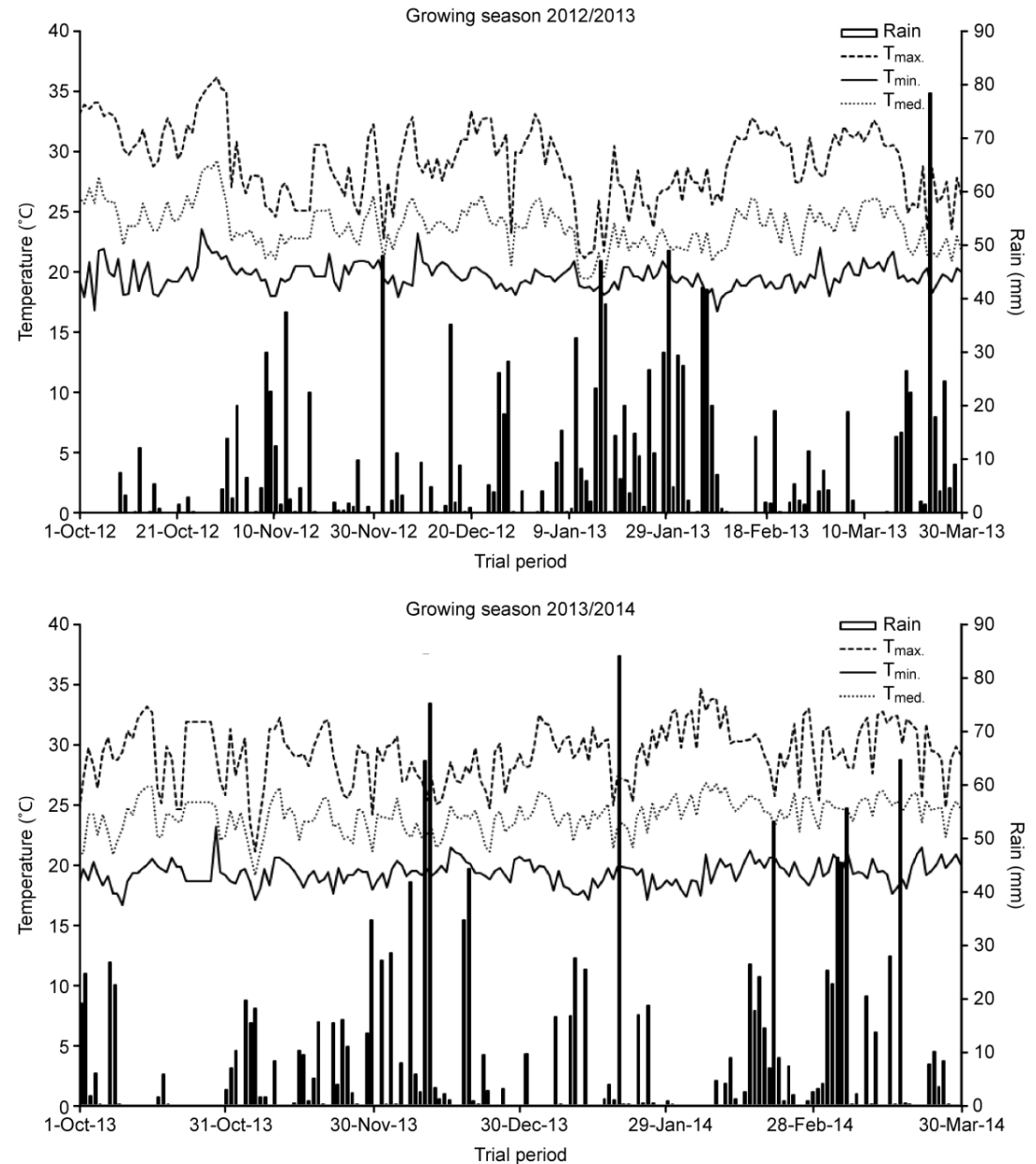

Fig 1. Average temperature and rain fall during the trials. Santo Antônio de Goiás, growing seasons 2012/13 e 2013/14.

shown that lower temperatures extend (Rodrigues et al., 2001) and higher temperatures shorten (Walter et al., 2010; Lago et al., 2008; Tao et al., 2008) the flowering period of rice. Nitrogen fertilization did not affect the flowering of rice, regardless of the form of application and doses used. However, other evaluated techniques, such as sowing depth, sowing density and phosphate fertilizers in the soil, significantly affected the early flowering of the parental line L106R, showing a high potential for use in the production systems of hybrid rice seeds. Regarding the difference in results between the two parental lines, it is important to reinforce the need for individualized studies for each line that may be used because each genotype may respond differently to each technique and a good production research program of production seeds is critical to the success of the activity.

Our results show that the techniques that affected the flowering of possible parental lineage $\mathrm{R}$ are promising when used alone or even in combination for the production systems of hybrid rice seeds. It is interesting to consider that application of pollinating lines in lines or blocks in the field could induce different times for early flowering. Therefore, the use of the techniques tested in our research can increase the amount of available pollen in the field, which would synchronize flowering and decrease the risk of the agricultural activity.

Among the techniques analyzed, the change in seeding rate between 10 and $80 \mathrm{~kg} \mathrm{ha}^{-1}$ of seeds had the greatest impact on the flowering of line L106R. There was a variation of 19 growing degree-days, an equivalent of about three days, which, although small, can be crucial for the success of hybrid rice seed production. According to Mao et al. (1998), if the pollinator line $(\mathrm{R})$ flowers before the male sterile line (A), there is a reduction in the productivity of hybrid seeds; however, when the male-sterile line (A) flowers two to three days before the pollinator line $(\mathrm{R})$, high productivity seeds are produced. These findings confirm the potential benefits of the techniques, as small adjustments in the early flowering of the parental lines can determine the productive potential of the seed production field. 
Table 2. Degree-days of parental lines of rice flowering as a function of genotype, sowing depth and growing season. Santo Antônio de Goiás, Growing season 2012/13 and 2013/14.

\begin{tabular}{lll}
\hline Factors & Degree-days & \\
\hline Genotypes & ${ }^{\circ} \mathrm{C}$ days ${ }^{-1}$ & \\
L106R & $1526 \mathrm{~b}$ & \\
Puitá $C L$ & $1715 \mathrm{a}$ & \\
Sowing depth(cm) & & \\
\hline 2.5 & $1617 \mathrm{~b}$ & \\
5.0 & $1617 \mathrm{~b}$ & \\
7.0 & $1627 \mathrm{a}$ & F Probability \\
Growing season & & - \\
\hline $2012 / 2013$ & $1359 \mathrm{~b}$ & $<0.001$ \\
$2013 / 2014$ & $1882 \mathrm{a}$ & - \\
\hline Factors & Mean square & 0.0054 \\
\hline Blocks & 509.59 & 0.1626 \\
Genotype (GEN) & 535399.28 & - \\
Error (a) & 157.52 & $<0.001$ \\
Sowing depths (SD) & 720.37 & 0.8281 \\
GEN ${ }^{\text {SD }}$ & 199.11 & 0.1491 \\
Error (b) & 97.63 & 0.9159 \\
Growing season (GS) & 4103039.60 & - \\
GEN*GS & 6.02 & \\
SD*GS & 257.51 & 11.01 \\
GEN*SD*GS & 124.88 & \\
Error (c) & & \\
\hline
\end{tabular}

*Means followed by the same letter vertically, do not differ by LSD test for $\mathrm{p} \leq 0.05$.
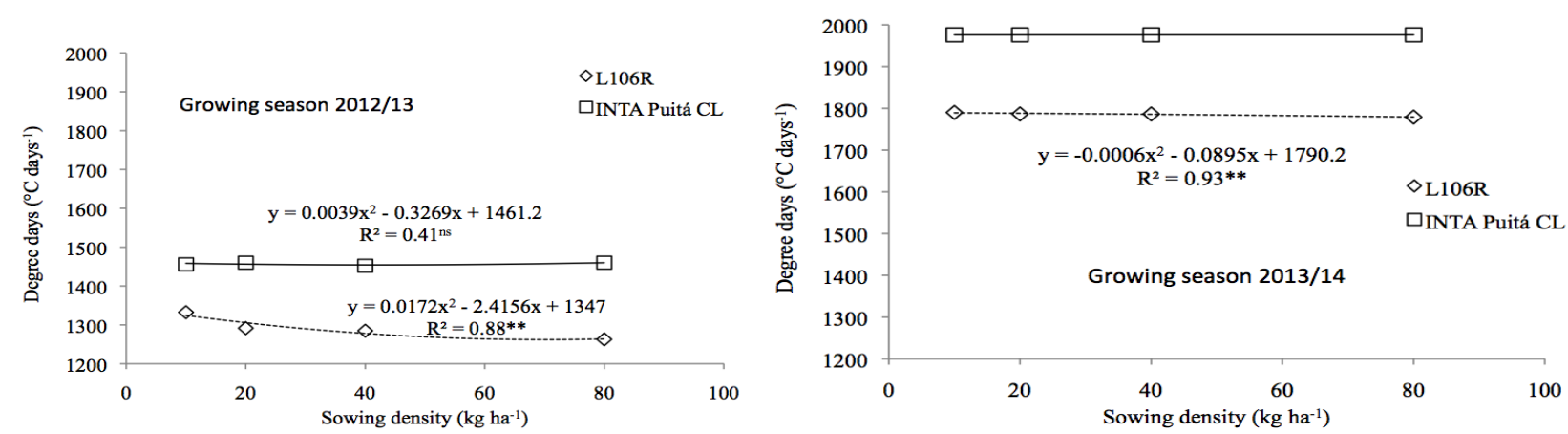

Fig 2. Effect of the interaction of the genotype, sowing density and growing season in the degree-days to reach the flowering of parental lines of rice. Santo Antônio de Goiás, growing seasons 2012/13 and 2013/14.

The development of techniques for the production of hybrid rice seed has been studied for over 30 years around the world; however, despite the progress achieved so far, the current system is still laborious, has high costs and a low seed yield. As a result, this could negatively impact the adoption of new technology with great potential to increase the production of this cereal worldwide. Thus, the continuation of efforts in this field of science, whether public or private, is essential for major breakthroughs.

\section{Materials and methods}

\section{Site description}

The experiments were conducted at Fazenda Capivara, Embrapa Rice and Beans, located in Santo Antônio de Goiás, $\mathrm{GO}$, at $16^{\circ} 28^{\prime} 00 " \mathrm{~S}$ and $49^{\circ} 17^{\prime} 00 " \mathrm{~W}$ and $823 \mathrm{~m}$ of altitude. The climate is tropical savanna and considered Aw according to the Köppen classification. There are two welldefined, normally dry seasons from May to September (autumn/winter) and two rainy seasons from October to April (spring/summer). Temperature and rainfall data were monitored during the experiment (Fig. 1).
The soil was classified as clay loam (kaolinitic and thermic Typic Haplorthox) acidic soil. Before the trials in October 2012 and October 2013, chemical analyses were performed at a depth of $0-0.20 \mathrm{~m}$ to characterize the experimental area (Table 1). The chemical analyses were performed according to the methodology proposed by Claessen (1997). The soil $\mathrm{pH}$ was determined in a $0.01 \mathrm{~mol} \mathrm{~L}^{-1} \mathrm{CaCl}_{2}$ suspension $(1: 2.5$ soil/solution), and the exchangeable $\mathrm{Ca}, \mathrm{Mg}$, and $\mathrm{Al}$ were extracted with neutral $1 \mathrm{~mol} \mathrm{~L}^{-1} \mathrm{KCl}$ in a $1: 10$ soil/solution ratio and determined by titration with a $0.025 \mathrm{~mol} \mathrm{~L}^{-1} \mathrm{NaOH}$ solution. Phosphorus and exchangeable $\mathrm{K}$ were extracted with a Mehlich 1 extracting solution $(0.05 \mathrm{M} \mathrm{HCl}$ in 0.0125 $\mathrm{M} \mathrm{H}_{2} \mathrm{SO}_{4}$ ). The extracts were calorimetrically analyzed for $\mathrm{P}$, and flame photometry was used to analyze $\mathrm{K}$. The base saturation values were calculated using the results of the exchangeable bases and total acidity at $\mathrm{pH} 7.0(\mathrm{H}+\mathrm{Al})$. Micronutrients were determined in the Mehlich 1 extract by atomic absorption, and the organic matter was determined by the method of Walkley and Black.

The experimental area has been cultivated in a no-tillage system (NTS) for three consecutive years, and soybean (Glycine $\max$ L.) was grown previously. A sprinkler irrigation system by a center pivot was used, and three crop 
Table 3. Degree-days of parental lines of rice flowering as a function of genotype, sowing density and growing season. Santo Antônio de Goiás, Growing season 2012/13 and 2013/14.

\begin{tabular}{|c|c|c|}
\hline Factors & \multicolumn{2}{|c|}{ Degree-days } \\
\hline Genotypes & \multicolumn{2}{|c|}{${ }^{\circ} \mathrm{C}$ days ${ }^{-1}$} \\
\hline L106R & \multicolumn{2}{|c|}{$1539 \mathrm{~b}$} \\
\hline Puitá CL & \multirow{2}{*}{\multicolumn{2}{|c|}{$1717 \mathrm{a}$}} \\
\hline$\underline{\mathrm{kg} \text { of seeds ha }}{ }^{-1}$ & & \\
\hline$\overline{10}$ & \multicolumn{2}{|c|}{1639} \\
\hline 20 & \multicolumn{2}{|c|}{1629} \\
\hline 40 & \multicolumn{2}{|c|}{1625} \\
\hline 80 & \multicolumn{2}{|c|}{1620} \\
\hline Growing season & & \\
\hline $2012 / 2013$ & \multicolumn{2}{|c|}{$1375 \mathrm{~b}$} \\
\hline $2013 / 2014$ & \multicolumn{2}{|c|}{$1880 \mathrm{a}$} \\
\hline Factors & Mean square & F Probability \\
\hline Blocks & 34.37 & - \\
\hline Genotype (GEN) & 503514.42 & $<0.001$ \\
\hline Error (a) & 76.85 & - \\
\hline Sowing density (SD) & 1044.38 & 0.0074 \\
\hline GEN * SD & 1221.08 & 0.0038 \\
\hline Error (b) & 190.02 & - \\
\hline Growing season (GS) & 4092174.98 & $<0.001$ \\
\hline GEN*GS & 2778.61 & 0.0003 \\
\hline $\mathrm{SD} * \mathrm{GS}$ & 587.09 & 0.0237 \\
\hline GEN*SD*GS & 691.46 & 0.0127 \\
\hline Error $(\mathrm{c})$ & 155.37 & - \\
\hline
\end{tabular}

* Means followed by the same letter vertically, do not differ by LSD test for $\mathrm{p} \leq 0.05$.
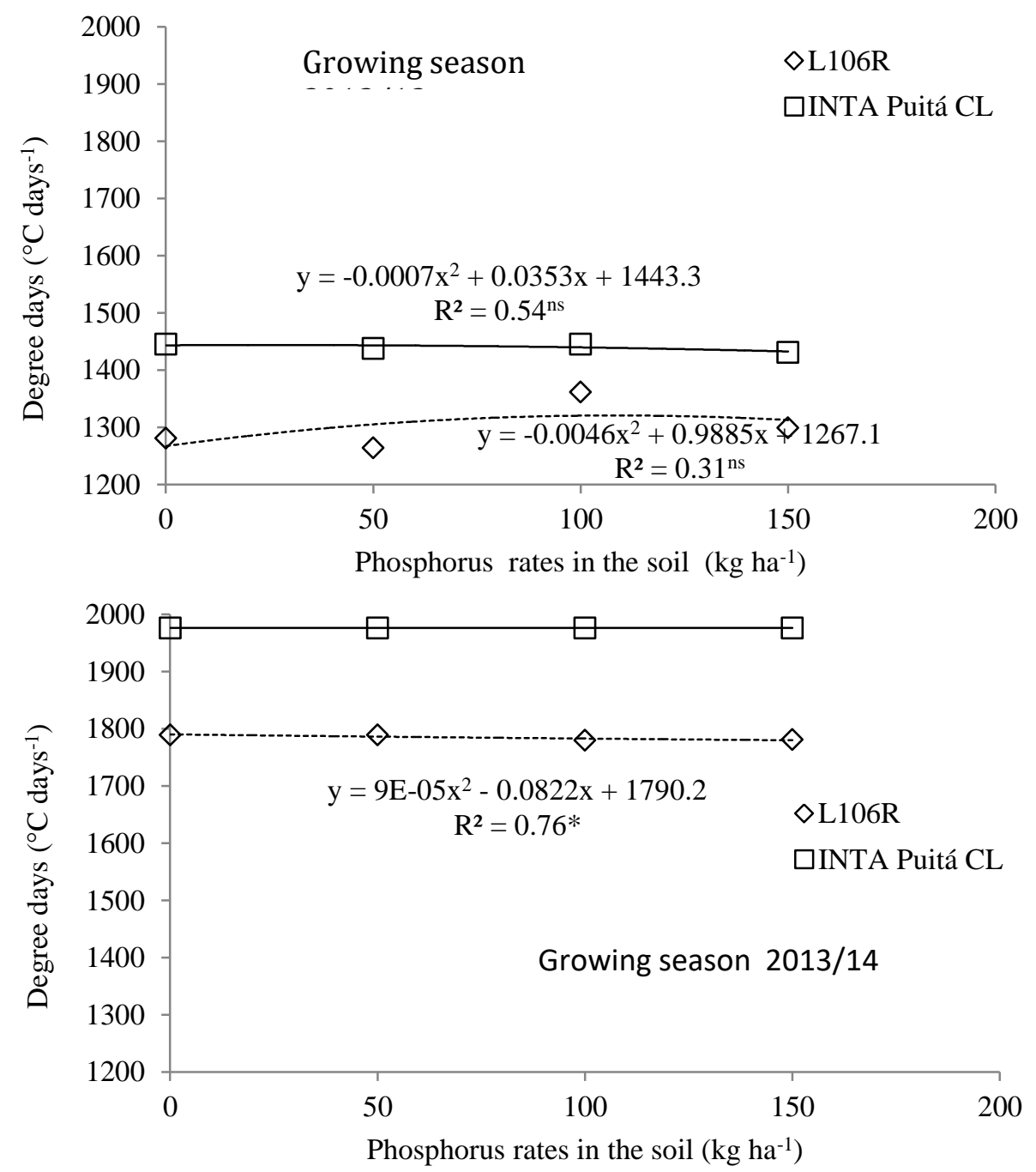

Fig 3. Effect of the interaction the genotype, phosphorus fertilization applied on the soil and growing season in the degree-days to reach the flowering of parental lines of rice. Santo Antônio de Goiás, growing seasons 2012/13 and 2013/14. 
Table 4. Degree-days of parental lines of rice flowering as a function of genotype, nitrogen rates applied on the soil and growing season. Santo Antônio de Goiás, Growing season 2012/13 and 2013/14.

\begin{tabular}{|c|c|c|}
\hline Factors & \multicolumn{2}{|c|}{ Degree-days } \\
\hline Genotype & \multicolumn{2}{|c|}{${ }^{\circ} \mathrm{C}_{\text {days }}{ }^{-1}$} \\
\hline$\overline{L 106 R}$ & \multicolumn{2}{|c|}{$1598 \mathrm{~b}$} \\
\hline Puitá $C L$ & \multirow{2}{*}{\multicolumn{2}{|c|}{$1715 \mathrm{a}$}} \\
\hline $\mathrm{N}$ rates on the soil $\left(\mathrm{kg} \mathrm{ha}^{-1}\right)$ & & \\
\hline 0 & \multicolumn{2}{|c|}{1656} \\
\hline 30 & \multicolumn{2}{|c|}{1656} \\
\hline 60 & \multicolumn{2}{|c|}{1656} \\
\hline 90 & \multicolumn{2}{|c|}{1659} \\
\hline \multicolumn{3}{|l|}{ Growing season } \\
\hline $2012 / 2013$ & \multicolumn{2}{|c|}{$1440 \mathrm{~b}$} \\
\hline $2013 / 2014$ & \multicolumn{2}{|c|}{$1873 \mathrm{a}$} \\
\hline Factors & Mean square & F Probability \\
\hline Blocks & 1011.12 & - \\
\hline Genotypes (GEN) & 218614.69 & $<0.001$ \\
\hline Error (a) & 96.45 & - \\
\hline $\mathrm{N}$ rates on the soil $(\mathrm{N})$ & 32.21 & 0.2486 \\
\hline GEN * N & 24.40 & 0.3611 \\
\hline Error (b) & 21.48 & - \\
\hline Growing season (GS) & 3006105.79 & $<0.001$ \\
\hline GEN*GS & 1251.53 & 0.05147 \\
\hline $\mathrm{N} * \mathrm{GS}$ & 41.31 & 0.9064 \\
\hline $\mathrm{GEN} * \mathrm{~N} * \mathrm{GS}$ & 187.13 & 0.4892 \\
\hline Error $(\mathrm{c})$ & 1798.35 & - \\
\hline
\end{tabular}

* Means followed by the same letter vertically, do not differ by LSD test for $\mathrm{p} \leq 0.05$.

Table 5. Degree-days of parental lines of rice flowering as a function of genotype, nitrogen rates applied by foliar and growing season. Santo Antônio de Goiás, Growing season 2012/13 and 2013/14.

\begin{tabular}{|c|c|c|}
\hline Factors & \multicolumn{2}{|c|}{ Degree-days } \\
\hline Genotypes & \multicolumn{2}{|c|}{${ }^{\circ} \mathrm{C}$ days $^{-1}$} \\
\hline$\overline{L 106 R}$ & \multicolumn{2}{|c|}{$1600 \mathrm{~b}$} \\
\hline Puitá CL & \multirow{2}{*}{\multicolumn{2}{|c|}{$1717 \mathrm{a}$}} \\
\hline $\mathrm{N}$ foliar rates $\left(\mathrm{kg} \mathrm{ha}^{-1}\right)$ & & \\
\hline 0 & \multicolumn{2}{|c|}{1656} \\
\hline 1.5 & \multicolumn{2}{|c|}{1660} \\
\hline 3.0 & \multicolumn{2}{|c|}{1660} \\
\hline 6.0 & \multicolumn{2}{|c|}{1661} \\
\hline Growing season & & \\
\hline 2012/2013 & \multicolumn{2}{|c|}{$1444 \mathrm{~b}$} \\
\hline 2013/2014 & \multicolumn{2}{|c|}{$1874 \mathrm{a}$} \\
\hline Factors & Mean square & F Probability \\
\hline Blocks & 939.06 & - \\
\hline Genotypes (GEN) & 218719.91 & $<0.001$ \\
\hline Error (a) & 95.06 & - \\
\hline $\mathrm{N}$ foliar rates $(\mathrm{N})$ & 79.02 & 0.1291 \\
\hline $\mathrm{GEN} * \mathrm{~N}$ & 24.36 & 0.5853 \\
\hline Error (b) & 36.71 & - \\
\hline Growing season (GS) & 2962959 & $<0.001$ \\
\hline $\mathrm{GEN} * \mathrm{GS}$ & 119.75 & 0.05741 \\
\hline $\mathrm{N} * \mathrm{GS}$ & 59.04 & 0.7211 \\
\hline $\mathrm{GEN} * \mathrm{~N} * \mathrm{GS}$ & 14.49 & 0.9535 \\
\hline Error (c) & 131.82 & - \\
\hline
\end{tabular}

* Means followed by the same letter vertically, do not differ by LSD test for $\mathrm{p} \leq 0.05$. 
Table 6. Degree-days of parental lines of rice flowering as a function of genotype, phosphorus rates applied in the soil and foliar and growing season. Santo Antônio de Goiás, Growing season 2012/13 and 2013/14.

\begin{tabular}{|c|c|}
\hline Factors & Degree-days \\
\hline Genotype & ${ }^{\circ} \mathrm{C}$ days ${ }^{-1}$ \\
\hline L106R & $1543 \mathrm{~b}$ \\
\hline Puitá CL & $1708 \mathrm{a}$ \\
\hline \multicolumn{2}{|l|}{ Rates of $\mathrm{P}_{2} \mathrm{O}_{5}$ applied in the soil $\left(\mathrm{kg} \mathrm{ha}^{-1}\right)$} \\
\hline 0 & 1623 \\
\hline 50 & 1617 \\
\hline 100 & 1641 \\
\hline 150 & 1622 \\
\hline \multicolumn{2}{|l|}{ Rates of foliar $\mathrm{P}_{2} \mathrm{O}_{5}\left(\mathrm{~kg} \mathrm{ha}^{-1}\right)$} \\
\hline 0 & 1628 \\
\hline 1.87 & 1624 \\
\hline 3.75 & 1627 \\
\hline 7.51 & 1623 \\
\hline \multicolumn{2}{|l|}{ Growing season } \\
\hline $2012 / 2013$ & $1371 \mathrm{~b}$ \\
\hline $2013 / 2014$ & $1880 \mathrm{a}$ \\
\hline Factors & F probability \\
\hline Blocks & 0.1487 \\
\hline Genotypes (GEN) & $<0.001$ \\
\hline $\mathrm{P}_{2} \mathrm{O}_{5}$ rates applied on the soil (Psoio) & 0.0731 \\
\hline $\mathrm{P}_{2} \mathrm{O}_{5}$ via foliar (Pfoliar) & 0.9581 \\
\hline Growing season (GS) & $<0.001$ \\
\hline GEN*Psoil & 0.1641 \\
\hline GEN*Pfoliar & 0.9364 \\
\hline GEN*GS & 0.0592 \\
\hline Psolo*Pfoliar & 0.9665 \\
\hline Psolo*GS & 0.0232 \\
\hline Pfoliar*GS & 0.9846 \\
\hline GEN*Pfoliar*Psoil & 0.9752 \\
\hline GS*Pfoliar*Psoil & 0.9700 \\
\hline GEN*GS*Psoil & 0.0473 \\
\hline GEN*GS*Pfoliar & 0.9736 \\
\hline GEN*GS*Pfoliar*Psoil & 0.9804 \\
\hline
\end{tabular}

coefficients $(\mathrm{Kc})$ were divided into four periods between the emergence and harvest to manage the application of water. In the vegetative stage, a $\mathrm{Kc}$ value of 0.4 was used. For the reproductive phase, two values of $\mathrm{Kc}$ were used: 0.7 to 1.0 in the initial phase and the reverse of these values in the final phase of maturation, i.e., 1.0 to 0.7 . Therefore, the control of irrigation respective of the depth of root system exploitation at $0.2 \mathrm{~m}$ was initiated with the available water capacity (AWC) at its maximum and successively subtracting the value of crop evapotranspiration until the total water reached the minimum limit of $40 \%$ of AWC (Doorenbos and Pruitt, 1976).

\section{Experimental design and treatments}

Five independent experiments were performed in the same experimental area for two consecutive seasons (2012/13 and 2013/14). The experiments were performed at three soil depths $(2.5,5.0$ and $7.0 \mathrm{~cm})$, four seeding densities $(10,20$, 40 and $80 \mathrm{~kg}$ seeds $\mathrm{ha}^{-1}$ ), four rates of $\mathrm{N}$ topdressing fertilization $\left(0,30,60\right.$ and $120 \mathrm{~kg} \mathrm{ha}^{-1}$ of $\left.\mathrm{N}\right)$, four rates of $\mathrm{N}$ foliar application $\left(0,1.5,3.0\right.$ and $\left.6.0 \mathrm{~kg} \mathrm{ha}^{-1}\right)$, four $\mathrm{P}_{2} \mathrm{O}_{5}$ application rates $\left(0,50,100\right.$ and $150 \mathrm{~kg} \mathrm{ha}^{-1}$ of $\left.\mathrm{P}_{2} \mathrm{O}_{5}\right)$ and four doses of foliar application of $\mathrm{P}_{2} \mathrm{O}_{5}(0,1.87,3.75,7.51 \mathrm{~kg}$ $\mathrm{ha}^{-1}$ of $\mathrm{P}_{2} \mathrm{O}_{5}$ ). In all the experiments, we used two rice cultivars (L106R and INTA Puitá CL), which are potential lines $\mathrm{R}$ in the production system of hybrid rice. The experimental design was a randomized complete block design with four replications. The first four experiments were in split plot scheme, with cultivars in the main plots and the depth, density, $\mathrm{N}$ in soil or $\mathrm{N}$ foliar in the subplots. In the $\mathrm{P}$ experiment, the scheme was factorial, with two cultivars with $\mathrm{P}$ in the soil and $\mathrm{P}$ foliar. The plots had a dimension of 1.75 $\mathrm{m}$ (five rice rows) x $5 \mathrm{~m}$ long. The usable area of the subplots consisted of three central lines of rice, disregarding $0.50 \mathrm{~m}$ on each side. To control the depth and seeding density, we performed adjustments on the seeder used (Semeato, model Personale Drill 13, Passo Fundo, RS, Brazil). Fertilization with nitrogen in the soil and foliar and the application of phosphorous were performed at the time of panicle differentiation (cotton point). The application of the soil phosphorus was carried out at the time of sowing.

\section{Crop management}

The experiments were sown on December $1^{\text {st }}, 2012$ and November $22^{\text {nd }}, 2013$. The average emergence of rice seedling took place five days after sowing. The row spacing was $0.35 \mathrm{~m}$, and the seeding rate, with the exception of the experiment involving different seed densities, was 80 viable seeds per meter. The fertilization was carried out based on soil analysis (Sousa and Lobato, 2003). Therefore, at sowing, we applied $110 \mathrm{~kg} \mathrm{ha}^{-1}$ of $\mathrm{P}_{2} \mathrm{O}_{5}$ and $20 \mathrm{~kg} \mathrm{ha}^{-1}$ of $\mathrm{N}$, supplemented with an additional $60 \mathrm{~kg} \mathrm{ha}^{-1}$ of $\mathrm{N}$ at topdressing 20 days after rice emergence from the crop. According to soil analysis, $\mathrm{K}$ was not needed. Cultural practices were performed according to standard 
recommendations for a rice crop to keep the area free from weeds, diseases and insects.

\section{Evaluations of traits}

To assess the time of flowering, the plots were observed daily. The full flowering date was defined as the time when $50 \%$ of the plants of the subplot had exposed panicles and were releasing pollen. The dates were converted into a number of degree-days (DD), from sowing to full flowering. For this conversion, we used the formula $\mathrm{DD}=$ average daily temperature - basal temperature, as the standard for calculation (McMaster and Wilhelm, 1997). The basal temperature used for rice cultivation was $10{ }^{\circ} \mathrm{C}$ (Gao et al., 1992).

\section{Statistical analyses}

The number of degree-days was evaluated using the analysis of variance. The model used for statistical analysis was the split plot for all experiments (factors were cultivars, $\mathrm{N}$ foliar rates, $\mathrm{N}$ rates on the soil, sowing density or soil depth and growing seasons), except for the $\mathrm{P}$ trial. In this experiment, the analysis was performed in a factorial design (factors were $\mathrm{P}$ rates on the soil, $\mathrm{P}$ foliar rates and growing seasons). Qualitative data were analyzed by comparing the means using LSD test, and statistical significance was defined as $\mathrm{p} \leq$ 0.05 . Quantitative data were analyzed by regression analysis. The statistical package SAS (SAS, 1999) was used for statistical analysis.

\section{Acknowledgment}

To the National Council for Scientific and Technological Development $(\mathrm{CNPq})$ for the financial support (Process 482320/2012-5 "Técnicas agronômicas para a sincronia de florescimento e elevação da alogamia na produção de sementes de arroz híbrido (Oryza sativa L.)").

\section{Conclusions}

Our study suggests that nitrogen fertilization applied to the soil or foliar at the time of panicle differentiation does not affect the time of flowering onset in the rice varieties INTA Puitá CL and L106R, which are potential R lines for the production of hybrid rice.

Agronomic techniques that include varying the sowing depth, seeding rate and phosphate fertilization affect the time of flowering in line L106R, a potential R line for the production of hybrid rice. Such techniques constitute potential alternatives for use in production systems of hybrid rice seeds.

\section{References}

Akhter M, Sabar M, Zahid MA, Ahamd M (2007) Hybrid rice research and developments in Pakistan. Asian J Plant Sci. 6:795-801.

Athwal DS, Virmani SS (1972) Cytoplasmic male sterility and hybrid breeding in rice. p. 615-620. In: Rice breeding. International Rice Research Institute, Los Baños.

Azzini LE, Rutger JN (1982) Amount of outcrossing on different male steriles of rice. Crop Sci. 22:905-907.

Bragantini C, Guimarães EP, Cutrim VA (2001) Male-sterile rice seed production. Pesqu Agropecu Bras. 36:273-277.

Butany WT (1957) Natural crossing in rice. Rice News Teller. 5:18-21.
Carnahan HL, Erickson JR, Tseng ST, Rutger JN (1972) Outlook for hybrid rice in USA. p. 603-607. In: Rice breeding. International Rice Research Institute, Los Baños.

Gao L, Jin Z, Huang Y, Zhang L (1992) Rice clock model: a computer model to simulate rice development. Agr Forest Meteorol. 60:1-16.

GRiSP (Global Rice Science Partnership) (2013) Rice almanac, 4th edn. International Rice Research Institute, Los Baños.

Huang P, Maruyama K, Sharma HL, Virmani SS (1994) Advances in hybrid rice seed. p. 63-70. In: Virmani SS (ed) Hybrid rice technology: new developments and future prospects. International Rice Research Institute, Los Banos.

Kempe K, Gils M (2011) Pollination control technologies for hybrid breeding. Mol Breeding. 27:417-437.

Kim SS, Jung JY, Jeong KS, Lee DS, Chen LJ, Suh HS (2007) Use of herbicide-resistant genic male sterility in hybrid rice seed production. Euphytica. 156:297-303.

Krishnakumar S, Nagarajan R, Natarajan SK, Jawahar D, Pandian BJ. NPK fertilizers for hybrid rice (Oryza sativa L.) productivity in alfisols of Southern Districts of Tamil Nadu. Asian J Plant Sci. 4:574-576.

Lago I, Streck NA, Alberto CM, Oliveira FB, Paula GM (2008) Impact of increasing mean air temperature on the development of rice and red Rice. Pesqu Agropecu Bras. 43:1441-1448.

Mao CX, Virmani SS, Kumar I (1998) Technological innovations to lower the costs of hybrid seed production. In: Virmani SS, Siddiq EA, Muralidharan K (ed). Advances in hybrid rice technology. International Rice Research Institute, Los Baños.

Mcmaster GS, Wilhelm WW (1997) Growing degree-days: one equation, two interpretations. Agr Forest Meteorol. 87:291-300.

Nascente AS, Crusciol CAC, Cobucci T (2013) The notillage system and cover crops Alternatives to increase upland rice yields. Eur J Agron. 45:124-131.

Oka HI, Morishima H (1967) Variations in the breeding system of a wild rice Oryza perennis. Evolution. 21:249258.

Oka HI (1988) Origin of cultivated rice. Japan Scientific Societies Press, Tokyo.

Planeta Arroz (2015) Qualidade do arroz produzido no Brasil ajuda a conquistar novos mercados. Available at: http://www.planetaarroz.com/site/noticias detalhe.php?idN oticia $=13658$. Acessed in October 4th, 2015.

Prasad R (2011) Aerobic rice systems. Adv Agron. 111:207236.

Qin J, Impa SM, Tang Q, Yang S, Yang J, Tao Y, Jagadish KSV (2013) Integrated nutrient, water and other agronomic options to enhance rice grain yield and $\mathrm{N}$ use efficiency in double-season rice crop. Field Crop Res. 148:15-23.

Ravi S, Ramesh S, Chandrasekaran B Exploitation of hybrid vigour in rice hybrid (Oryza sativa L.) through green manure and leaf colour chart (LCC) based $\mathrm{N}$ application. Asian J Plant Sci. 6:282-287.

Rocha DR, Fornasier-Filho D, Barbosa JC (2011) Effects of plant density on yield of green ears of corn cultivars. Hort Bras. 29:392-397.

Rodrigues O, Didonet AD, Lhamby JCB, Bertagnolli PF, Luz JS (2001) Quantitative response of soybean flowering to temperature and photoperiod. Pesqu Agropecu Bras. 36:431-437.

Sampath S, Mohanty HK (1954) Cytology of semi-sterile rice hybrid. Curr Sci India. 23:182-183.

SAS Institute (1999) Procedure guide for personal computers. Version 5. SAS Institute Inc., Cary, NC. 
Sakai KI, Narise T (1959) Studies on the breeding behavior of a wild rice (Oryza rufipogon and Oryza perennis). Annu Rep Nat Inst Gen. 9:64-65.

Taillebois J, Guimarães EP (1988) Improving outcrossing rate in rice (Oryza sativa L.). In: Hybrid Rice. International Rice Research Institute, Los Baños.

Tan Y, Sun M, Corke H (2002) Physicochemical properties of an elite rice hybrid. J Sci Food Agric. 82:1628-1636.

Tao F, Hayashi Y, Zhang Z, Sakamoto T, Yokozawa M (2008) Global warming, rice production, and water use in China: developing a probabilistic assessment. Agr Forest Meteorol. 148:94-110.

Virmani SS (1996) Hybrid rice. Adv Agron. 57:1-377.

Virmani SS (2003) Advances in hybrid rice research and development in the tropics. Hybrid rice for food security, poverty alleviation, and environmental protection. In: Virmani SS (ed) Proceeding of the $4^{\text {th }}$ international symposium on hybrid rice. Los Banos, 2003.
Walter LC, Streck NA, Rosa HT, Krüger CAMB (2010) Climate change and its effects on rice. Ci Rural. 40:24112418.

Xu S, Li B (1988) Managing hybrid rice seed production. In: Hybrid rice. International Rice Research Institute, Los Baños.

Yuan LP (2003) Recent progress in breeding super hybrid rice in china. Hybrid rice for food security, poverty alleviation and environmental protection. In: Virmani SS (ed) Proceeding of the $4^{\text {th }}$ international symposium on hybrid rice. Los Banos, 2003. 